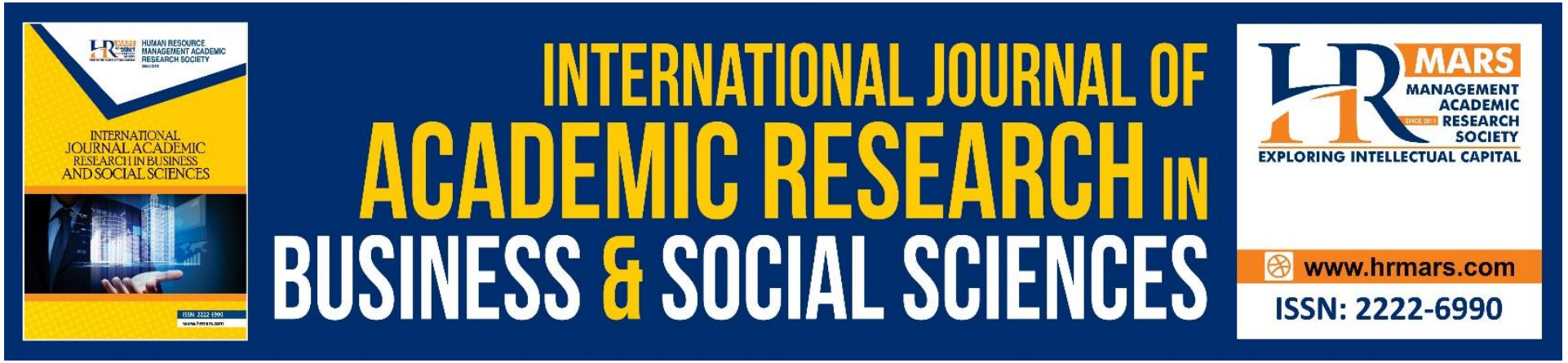

\title{
Students' Learning Status and Expectations with Online Distance Learning
}

\section{Aminabibi Saidalvi, Wan Farah Wani Wan Fakhruddin}

To Link this Article: http://dx.doi.org/10.6007/IJARBSS/v11-i9/10776

DOI:10.6007/IJARBSS/v11-i9/10776

Received: 01 July 2021, Revised: 25 July 2021, Accepted: 19 August 2021

Published Online: 06 September 2021

In-Text Citation: (Saidalvi \& Fakhruddin, 2021)

To Cite this Article: Saidalvi, A., \& Fakhruddin, W. F. W. W. (2021). Students' Learning Status and Expectations with Online Distance Learning. International Journal of Academic Research in Business and Social Sciences, 11(9), 1-17.

\section{Copyright: @ 2021 The Author(s)}

Published by Human Resource Management Academic Research Society (www.hrmars.com)

This article is published under the Creative Commons Attribution (CC BY 4.0) license. Anyone may reproduce, distribute, translate and create derivative works of this article (for both commercial and non-commercial purposes), subject to full attribution to the original publication and authors. The full terms of this license may be seen at: http://creativecommons.org/licences/by/4.0/legalcode

Vol. 11, No. 9, 2021, Pg. 1 - 17

Full Terms \& Conditions of access and use can be found at http://hrmars.com/index.php/pages/detail/publication-ethics 


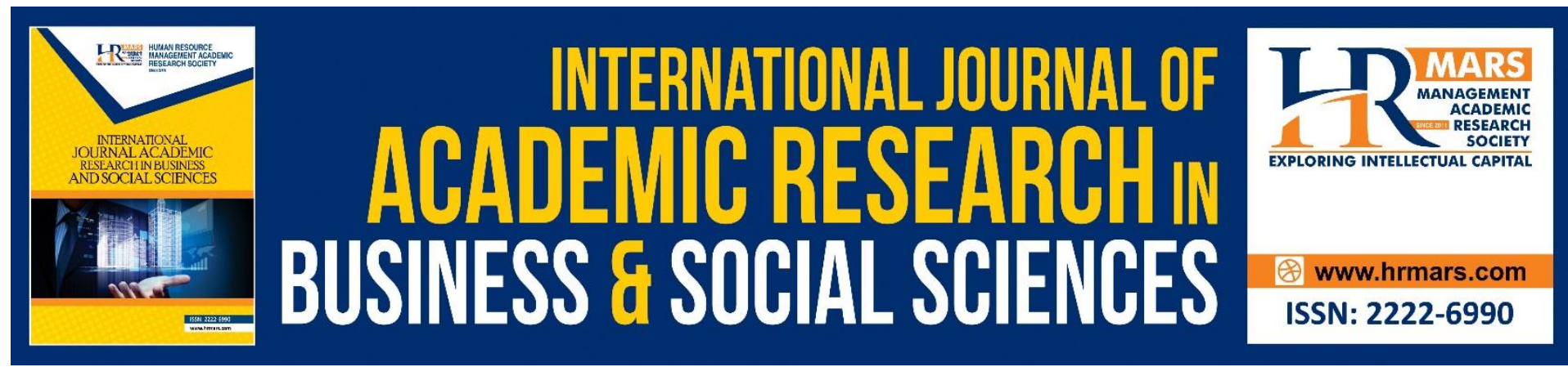

\title{
Students' Learning Status and Expectations with Online Distance Learning
}

\author{
Aminabibi Saidalvi ${ }^{1}$, Wan Farah Wani Wan Fakhruddin ${ }^{2}$ \\ ${ }^{1}$ Universiti Teknologi MARA, Cawangan Johor, Kampus Pasir Gudang, Malaysia, ${ }^{2}$ Universiti \\ Teknologi Malaysia, Skudai, Johor, Malaysia \\ Email: aminabibi@uitm.edu.my
}

\begin{abstract}
The Covid-19 pandemic in Malaysia, from the first wave in March 2020 till to-date the third wave has disrupted all formal face-to-face learning at all levels of education. A shift in the teaching mode was necessary from face-to-face to any accessible and feasible online distance learning (ODL) platform. However, due to lack of necessary technological equipment and an unsupportive environment, students are still reluctant to adopt online distance learning, particularly in rural areas. Furthermore, little was known about the readiness of engineering students at Diploma level to experience this new mode of learning. This study looked into students' ODL learning status and their expectations for ODL educational decisions. Data was collected for three weeks in a university in the southern region of Peninsular Malaysia using online Google Forms. Data was analysed descriptively and direct quotes from the open-ended section of the questionnaire were presented to support the descriptive analysis. The data highlights the need to involve many stakeholders and properly plan the ODL instructions for effective technology-based education. The outcomes of this research will help the educators, students and the government to redesign and restructure ODL post-Covid-19 for successful teaching and learning.
\end{abstract}

Keywords: Online Learning, Online Distance Learning (Odl), Learning Status, Expectations, Covid-19

\section{Introduction}

The World Health Organization (WHO) declared the coronavirus disease (COVID-19) a "pandemic" on March 11, 2020, prompting countries around the world to implement lockdown, social and physical separation, and avoid face-to-face teaching and learning in order to curb the spread of this highly contagious disease (WHO, 2020; Gonzalez et al. 2020; Pelmin, 2020). For over a year, Malaysia, like many other nations across the world, used the Movement Control Order (MCO), Conditional Movement Control Order (CMCO), and Recovery Movement Control Order (RMCO) at various levels to flatten the curve the spread of Covid-19 till to-date. Students and instructors in higher education institutions have been impacted intensely by the extraordinary changes brought on by the Covid-19 pandemic, as all teaching and learning activities must be performed virtually (Sim, Sim \& Quah, 2021; Chung, Noor \& Mathew, 2020). Many of the world's most prominent institutions have fully embraced 
online learning as a means of maintaining educational continuity. Similarly, all Malaysian public and private institutions have to conduct teaching and learning activities through online learning until the end of December 2020 (Malaysian Ministry of Higher Education, 2020), which was later extended until to-date the second quarter of 2021.

Online distant learning (ODL) encompasses a variety of delivery methods, including online learning, open learning, web-based learning, computer-mediated learning, blended learning, and mobile learning. In synchronous or asynchronous contexts, ODL is defined as learning interactions using different devices (e.g., mobile phones, tablets, etc.) with internet access (Singh \& Thurman, 2019). Lectures, assignments, group work, presentations, and evaluations were all organised and carried out with the use of technology in less than two weeks. Many studies have been conducted to determine the efficacy of implementing ODL even before the pandemic (Vitoria, \& Nurmasyitah, 2018; Aggarwal, Comyn \& Fonseca, 2020) and since then, resulted many universities promoting and encouraging ODL. This mode of new learning norm provides flexibility, time savings, ease of use, and greater environmental control (Paul \& Jefferson, 2019). Despite all of the advantages, the majority of students are still struggling with e-learning, insufficient equipment, and an unfriendly environment making the adoption of home-based e-learning even more difficult (Sim, Sim, \& Quah, 2021). In addition, a study by Alea (2020) highlighted that teachers were highly aware of the presence and consequences caused by the COVID-19 pandemic.

This research is based on online distance learning theory, and it focuses on the experiences of students during ODL in terms of the learning status. In order to enhance the quality of teaching and learning in this new normal, it is critical to explore the learning status of ODL perceived by the students. The investigation based on the perspectives of Diploma level students have received very little attention. When ODL was completely implemented for over a year, Diploma level students had only begun their higher tertiary study experience. This shift from secondary school to higher education, as well as from face-to-face traditional instruction to online learning, would undoubtedly have had an impact on students. Thus, it is essential to examine the perspective of the Diploma students in terms of their learning status during COVID-19 pandemic. Furthermore, the students' expectations about ODL's instructional decisions were also investigated. As a result, the following research questions were addressed in this study:

1. What are the Diploma students' perspectives in relation to learning status on ODL during the Covid-19 pandemic?

2. What are the Diploma students' expectations for ODL educational decision during the Covid-19 pandemic?

\section{Review of the Literature \\ Online Distance Learning (ODL)}

Online distance learning or remote learning occurs when an instructor who is physically present in a different location than the student provides instruction at separate times (Moore's Transactional Distance Theory,1980),. There are numerous definitions and interpretations of ODL, as previously documented in the literature. E-learning, online learning and distance learning environments are all terms used by different people (Moore, 2010). The word e-Learning is most likely to have originated in the 1980s, however others are unsure, and there are differing perspectives on the concept. Besides, Tavangarian et al (2004), included the constructivist theoretical model as a framework for many earlier definitions by Ellis (2005); Nichols (2003); Benson (2002); Clark (2002), of that e-Learning is not only 
procedural but also shows some transformation of an individual's experience into the individual's knowledge through the knowledge construction process. Online learning can be the most difficult to describe. Some studies identify the differences by referring to online learning as "wholly" online learning (Oblinger, Oblinger, \& Lippincott, 2005), while others refer to technology as the medium in which it is delivered (Lowenthal, Wilson, \& Parrish, 2009). Most studies define online learning as access to learning experiences through the use of technology (Benson, 2002; Carliner \& Boswood, 2004; Conrad, 2002), and it is further defined as not only the accessibility of online learning but also its connectivity, flexibility, and ability to promote a variety of interactions (Ally, 2004; Hiltz \& Turoff, 2005; Oblinger \& Oblinger, 2005).

Thus, it is clear that the terms are frequently interchanged, and the commonalities found in all definitions are that some form of instruction takes place between two parties (a learner and an instructor), that it takes place at various times and/or locations using any feasible platform and that it uses a variety of instructional materials.

\section{Online Distance Learning Related Theories}

Several theories have made significant contributions to ODL. Constructivism theory, as an example encourages autonomous learning in which learners are active builders of knowledge, meaning and understanding based on their own learning experience (Wang, 2014). John Dewey elaborated on this by stating that learning is a collection of practical social experiences in which learners learn by doing, cooperating, and reflecting with others (Picciano, 2017). Besides, in more recent years, when online learning has grown more significantly, online collaborative learning $(\mathrm{OCL})$ theory promotes collaborative learning, knowledge development, and proposes the use of internet in reconstructing formal, nonformal, and informal education (Harasim, 2012). The idea that the facilitator (teacher) should be in charge of the knowledge building process and the three phases of knowledge creation; idea generation, idea organisation, and intellectual convergence, sparked a lot of debate and engagement among the members of the social community. Reviewing important learning theories help in scaffolding and providing a base to conduct the current study.

\section{Perceptions of Students on ODL}

Since the onset of the Covid-19 pandemic and the discontinuation of physical face-toface classes, a considerable number of research in the literature explored students' perceptions of ODL (Mathew \& Chung, 2021; Sim, Sim, \& Quah, 2021; Demuyakor, 2020; Khan et al., 2021; Singh \& Thurman, 2019; Lau \& Shaikh, 2012; Lee, 2020). Mathew and Chung (2021) used a simple sampling technique to conduct a comparative research with a total of 608 diploma and degree university students across Malaysia to investigate opinions on ODL in the context of COVID-19. According to the survey, some students have positive perceptions on ODL implementation, while others believe it should be discontinued in the next semester owing to challenges such as inadequate internet connectivity, budget constraints, and time management issues. Another study by Sim, Sim, and Quah (2021) studied the acceptability, factors, and difficulties of online learning among 156 university students in Sarawak. The findings revealed that students embrace online learning with a moderate level of acceptance, with enthusiasm, self-efficacy, satisfaction, and the improvement of English language skills being the four key variables that facilitated learning. However, among the challenges students face in online learning was the pace with which teaching and learning is delivered, students' attitudes, struggles, and stress. 
Demuyakor (2020) found that students perceived online learning was beneficial in a research involving 360 Ghanaian foreign students. The majority of them strongly agreed that online compared to those in traditional classrooms. Another research of 184 university students in Delhi's National Capital Territory (NCT) found that when in ODL mode, students felt they have more freedom and connected to their teachers. It was shown that students with various learning styles benefitted from flexible learning modes and study time periods. In fact, it was discovered that more than half of the total number of respondents felt comfortable learning on an online platform, despite the fact that they are not in a physical environment (Khan et al., 2021; Singh \& Thurman, 2019). In addition, the majority of students have positive perceptions regarding e-learning and the efficacy of communication between teacher-students even without any face-to-face interaction. This is due to the fact that the quick replies students receive during online learning conversations similar to during traditional face-to-face classes function as a "catalyst" in the learning process (Khan et al., 2021). Sit, Chung, Chow and Wong (2005) performed a similar research with 198 nursing students in Hong Kong and found that ODL to be convenient since they were able to choose their own learning time and felt accountable for their studies. In addition, Lau and Shaikh (2012); Funa and Talaue (2021) highlighted that students' technological gadgets and internet efficacy, as well as personal characteristics such as gender, ethnicity, course year level, and financial aid status, are factors contributing to students' online learning readiness.

Another similar research reported that around 52 percent of students in Sabah, Malaysia, do not have internet access due to poor online learning infrastructures and restricted internet connectivity (52 Peratus, 2020). Lee (2020) added that this situation makes it difficult for students to communicate with lecturers, engage with friends, and gain access to laboratories. Students in rural areas of Malaysia perceived ODL as difficult owing to restricted internet connection, which has an impact on their education. Furthermore, studies have revealed that age, gender, prior computer literacy knowledge, and preferred learning styles of individuals are factors that contribute to technology acceptance among students. It means that the more knowledgeable they are about technology, the more receptive they will be to their online learning classes (Demuyakor, 2020; Bali \& Liu, 2018). On the other hand, ineffective internet connections and support technology for students and staff (Rasheed, Amirrudin, \& Nor Aniza, 2020; Anderson \& Perrin, 2018; Chuang, Weng, \& Chen, 2018), lack of interaction with lecturers and peers (Vanslambroucka, Zhu, Lombaerts, Philipsen, \& Tondeur, 2018; Bali \& Liu, 2018), and increased stress and study load (Vanslam (Vanslambroucka et al., 2018; Ravi, 2014) were among the issues found to be the challenges in conducting ODL.

A thorough examination of the research on students' perceptions of their ODL learning experience reveals a number of gaps. Few studies have looked into how Diploma students experience ODL. These are secondary school leavers who have fully experienced face-to-face traditional learning mode throughout their schooling experience. The experience of joining tertiary level education is already a new adventure for them. On top of this new adventure, is learning university courses using ODL mode. Thus, it is necessary to investigate the students' experience in terms of their learning status when facing this new norm. Furthermore, most of the investigation in the literature focus on students' perceptions of ODL in terms of challenges and views of learning ODL mode. Little have been found looking into the learning status and the expectations on the educational decisions to continue learning using ODL from the perspective of Diploma students. This study investigated the students experiences in relation to learning status of Diploma students and also the expectations they have on ODL's educational decisions in Malaysia. The findings will be useful to educators, 
curriculum designers, institutions of higher learning, and the government in implementing ODL in Malaysian universities.

\section{Research Methodology}

The research methodology for the current study embarked upon receiving approval from the Research Ethics Committee of the University. The research participants were Diploma students at Universiti Teknologi MARA Johor, Pasir Gudang Campus. A total of 1490 students enrolled in Diploma engineering courses and according to Krejcie and Morgan's (1970) Table of Sample Size, a minimum of 306 participants should be sought as research samples. A random sampling technique was utilised and a set of questionnaire was distributed online using Google Forms through class teachers WhatsApp groups for data collection. The study managed to collect responses from 486 responses which was more than the expected number of samples. The questionnaire used in this study was derived from a few earlier studies on ODL (Bczek, et al., 2021; Selvanathan, Hussin, \& Azazi, 2020; Kapasia, et al., 2021). The questionnaire is divided into five sections: demographics, online distance learning mode, synchronous and asynchronous learning experience, ODL Learning Environment, and ODL in the future, with Cronbach alpha values of $0.57,0.78,0.77,0.58$, and 0.83 , respectively. The scale used a 5-point Likert scale, with 1 being the lowest and 5 being the highest. The first section on demographics covers two items; to determine the gender and their course of study in their Diploma course, five questions looking into the participants' ODL learning mode, which included gadget selection, ownership of gadgets and mode of assignment submission, ten questions on the synchronous and asynchronous learning experiences, eight questions investigated their ODL learning environment and finally six questions on their future learning expectations using ODL. Two open-ended questions about ODL mode experiences and future expectations were also included to allow students to freely voice their experiences and expectations. Using the formula below in Microsoft Excel, the internal consistency of the items were calculated and a Cronbach alpha value of 0.78 was achieved which indicates an acceptable consistency of the items in the questionnaire (Taber, 2018).

$$
\alpha=\frac{\kappa}{\kappa-1}\left(1-\frac{\sum_{\nu l}}{\nu \tau}\right)
$$

The course lecturers assisted in circulating the Google Form consisting the questionnaire to student WhatsApp groups to collect data. The subjects' written informed permission to use data for investigation was also obtained. To better understand the distribution of research participants, mode of learning, learning environment, and view on the future of ODL, descriptive statistics highlighting the frequencies and percentages were generated. Results are presented in the form of charts and tables in the following sections. The open ended questions were taken verbatim to support the descriptive analysis.

\section{Results}

\section{Respondent Characteristics}

The following are the characteristics of Diploma course students participated in the study. Table 1 shows the gender distribution, whereas Figure 1 depicts the respondents' Diploma majors. 
Table 1: Gender Distribution

\begin{tabular}{|l|c|c|}
\hline Gender & $\mathbf{n}$ & $\begin{array}{c}\text { Percentage } \\
\text { (\%) }\end{array}$ \\
\hline Male & 278 & 57.2 \\
\hline Female & 208 & 42.8 \\
\hline
\end{tabular}

Table 1 depicts the gender distribution of the 486 samples of the study. Data shows 57.2 percent $(n=278)$ of the students are male and 42.8 percent $(n=208)$ are female. This illustrated male respondents are more by 14.4 percent than female respondents. However, in this study the difference in views based on gender are not being investigated. This data merely illustrates that the perspectives of students are extracted from both genders.

Figure 1 below indicates the engineering courses enrolled by the respondents.

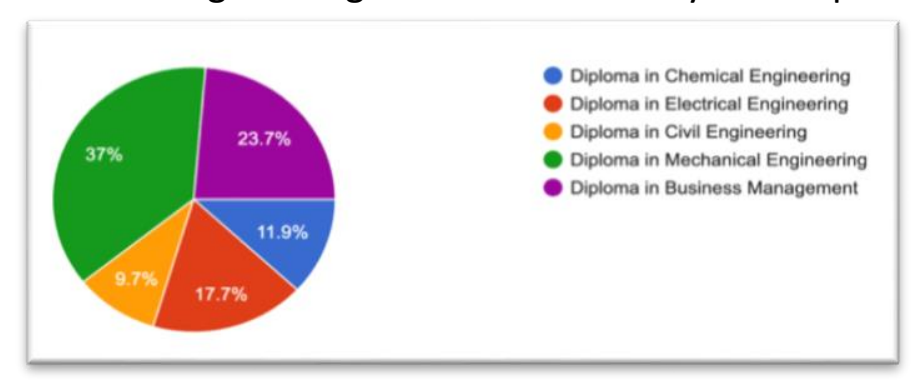

Figure 1: Engineering courses of the respondents

It can be noted from Figure 1 that the majority of responders with a total of 180 students (37\%) were from the Diploma of Mechanical Engineering, followed by the 23.7 percent Diploma of Business Management ( $n=115)$, the Diploma of Electrical Engineering with 17.7 percent ( $n=86), 11.9$ percent $(n=58)$ are Diploma of Chemical Engineering students and finally 47 students from the Diploma of Civil Engineering (9.7\%).

\section{ODL Learning Status}

In this section, students' ODL experiences in relation to learning status are investigated from the students' perspectives. These include investigating the learning platforms, attendance to virtual conducted lessons, technological gadgets used for learning and mode of assignment submissions were investigated.

\section{ODL Platform and Attendance to Lessons}

Table 2, shows the platforms used by students to attend to virtual lessons. 
Table 2 : Platforms and attendance to ODL

\begin{tabular}{lc}
\hline 1. Platforms used for ODL & $\%$ \\
\hline Zoom & 2.8 \\
Google Meet & 52.7 \\
Padlet & 7.4 \\
Microsoft Teams & 24.4 \\
YouTube & 6.9 \\
Other platforms (Telegram, Google Classroom, Webex, & 5.8 \\
Skype, WhatsApp, UFuture & \\
\hline \multicolumn{2}{l}{ Attend all the online classes that lecturers conduct } \\
\hline Yes & \\
Sometimes & 92.4 \\
No & 5.6 \\
\hline
\end{tabular}

It was noted that 52.7 percent $(n=256)$ of the students used Google Meet as their main platform to interact with lecturers and peers. This is followed by Microsoft Teams with 24.4 percent $(n=118)$ and YouTube with 6.9 percent $(n=33)$. The least preferred was Zoom with only 2.8 percent $(n=14)$. This is in contrast with the findings of Mathew \& Chung (2021). In their study, they found that Google classroom and YouTube were more favourable to students compared to other learning platforms. In addition, it was important to note whether students attended all the ODL classes that the lecturers conducted. Interestingly, it was evident that the majority of students with 92.4 percent $(n=449)$ attended all the classes conducted by their lecturers. Only 2 percent $(n=9)$ of the respondents did not attend to classes.

\section{Technological gadgets}

This section illustrates the technological gadgets that students use for ODL and the owner of the gadgets. Students were asked to choose the type of gadgets they use during classes. and state the owner of the gadgets they use.

Table 3: Technological gadgets and ownership

\begin{tabular}{lc}
\hline \multicolumn{1}{c}{ 2. Gadgets used to attend to online classes } & $\%$ \\
\hline Android mobile phone & 23 \\
iPhone & 9 \\
Laptop & 66 \\
Personal Computer & 1.3 \\
iPad & 0.5 \\
Friend's laptop & 0.2 \\
\hline 3. Whose technological gadgets used for ODL? & \\
\hline Own & 93.6 \\
Parents & 3.8 \\
Other family members & 2.6 \\
Hired from neighbours & 0 \\
Friends & 0 \\
\hline
\end{tabular}

Table 3 illustrates the technological gadgets students use during ODL and the ownership of the gadgets. It was reported that the most frequent gadgets used by the respondents for 
ODL were laptops (66\%) and android mobile phones (23\%). The least used technological gadgets were ipads $(0.5 \%)$ and friend's laptop ( 0.2 percent). In terms of the ownership of these gadgets, 93.6 percent $(n=455)$ reported that the gadgets they used were their own, followed by 3.8 percent $(n=18)$ were using their parents' and another 2.6 percent $(n=13)$ used gadgets that belong to other family members.

Next, Table 4 below highlights the platforms students use to submit assignments to course lecturers.

Table 4: Platforms used for submission of assignments

\begin{tabular}{lc}
\hline 4. Mode used for submission of assignment & \\
\hline Google Drive & 36 \\
Microsoft Teams & 39 \\
YouTube & 2 \\
WhatsApp & 12 \\
Telegram & 4 \\
Padlet & 3 \\
Other platforms (Google Classroom, Instagram, Email) & 4 \\
\hline
\end{tabular}

It was noted from Table 4 that students use various platform for assignment submissions. Even though the main platform used for learning was Google Meet, the students submit their assignments mainly on Microsoft Teams (39\%) and 36 percent through Google Drive. Other popular platforms for assignment submissions are WhatsApp (12\%), Telegram (4\%) and Padlet (3\%). There are also some students who submit assignments using Google Classroom, Instagram and email. The least frequent mode used for submission was YouTube (2\%).

\section{Students Expectations in ODL}

It is essential to explore students' opinions and expectations of ODL's educational decisions during the Covid-19 pandemic. The last section of the survey attempted to find out how students see ODL in the future, and their expectations on this mode of learning. The findings are presented in Table 5 below. 
Table 5: Expectations on Educational Decisions of ODL

\begin{tabular}{lll}
\hline Expectations of ODL in the future & (n) & $\%$ \\
\hline ODL should not be continued in the future & 60 & 23.3 \\
ODL helps to shape me into a better person & 16 & 6.2 \\
$\begin{array}{l}\text { Lecturers should give extra consideration with the students } \\
\text { It is hoped that there is no external constraint to occur in the }\end{array}$ & 10 & 3.9 \\
future & 6.2 \\
$\begin{array}{l}\text { The implementation of ODL should be improved } \\
\text { The learning institution should play a greater role in making sure }\end{array}$ & 36 & 17.9 \\
$\begin{array}{l}\text { ODL runs smoothly } \\
\text { ODL should help me to get good grades }\end{array}$ & 45 & 17.5 \\
$\begin{array}{l}\text { Students have to be well prepared for ODL in the future } \\
\text { It is good to be back to physical classes }\end{array}$ & 10 & 3.9 \\
It is hoped for ODL to improve my understanding towards the & 8 & 10.9 \\
lessons better & 3.1 \\
$\begin{array}{l}\text { I have positive expectation of ODL as future way of learning } \\
\text { effectively }\end{array}$ & 15 & 5.8 \\
\hline
\end{tabular}

Table 5 shows the participants expectations on educational decisions of ODL. It was found that there are three main expectations of the students related to ODL. The main concern of the respondents was to discontinue ODL (23.3 percent; $n=60)$. This is self-explanatory when in item 9 on Table 5 students expect their studies to be back to physical classes (10.9\%). Most of the students were dissatisfied with the implementation of virtual learning mode during this pandemic and were hoping for improvement. It was noted that 17.9 percent of the respondents $(n=46)$ expects ODL implementation should be improved. This is followed with the expectation that ODL should be helping them in getting good grades (17.5\%; $n=45)$.

These respondents' opinions were further supported when, in open-ended questions, students revealed their future expectations of ODL. Table 6 shows direct quotes of students about what they expect from ODL in the future. 
Table 6: Students' Expectations of ODL

\begin{tabular}{|c|c|}
\hline 1 & "I think I don't want any ODL classes anymore" \\
\hline 2 & "Lets just make sure no ODL anymore" \\
\hline 3 & "i hope it will be end for sem 4" \\
\hline 4 & "i hope there's no more ODL in the future." \\
\hline 5 & "I hope this ODL is last for this sem" \\
\hline 6 & "I hope that ODL will not be continue in the next semester" \\
\hline 7 & "not happened again in next semesters." \\
\hline 8 & $\begin{array}{l}\text { "I hope ODL is just a temporary alternative not a permanent } \\
\text { because ODL is not } 100 \% \text { effective to students" }\end{array}$ \\
\hline 9 & "I hope that odl will not be the reason i give up with my studies" \\
\hline 10 & $\begin{array}{l}\text { "I hope ODL will end soon because students are hard to } \\
\text { understand the subjects with ODL" }\end{array}$ \\
\hline 11 & "i just hope ODL is end and covid end bacause i can't adapt it" \\
\hline 14 & "Less assignment" \\
\hline 15 & $\begin{array}{l}\text { "I hope ODL can be more relax and not to do like assignments all } \\
\text { the time as it can make students feel bothered and stress" }\end{array}$ \\
\hline 16 & $\begin{array}{l}\text { "I just hope the ODL did force students to do too much } \\
\text { assignments in certain time as that makes us loss our efficiency } \\
\text { in doing our own work." }\end{array}$ \\
\hline 23 & $\begin{array}{l}\text { "I hope I won't fail each semesters that are using ODL method as } \\
\text { it is my greatest fear. I just don't want to upset my parents." }\end{array}$ \\
\hline
\end{tabular}

Table 6 illustrates the students' expectations on the educational decision to use ODL in the future. Data was taken verbatim from students' opinion written in the open-ended section of the questionnaire. No editing of grammatical errors was done to the data to show the exact voice of the students. When asked on their agreement that ODL will be the future for their learning, it was noted that respondents hope that ODL will no longer be implemented in the future or in the upcoming semesters. This can be proven from item 1 until item 11 where students do not want the ODL more to continue in the future and hope to be back to campus to learn face-to-face. Students expressed their worry of difficultly in understanding lessons, struggling in adapting to new mode of learning, and grappling in continuing course of study. Students believe ODL to be completely unproductive for students, and worried that they might withdraw from studies.

It is also important to find out ways ODL could be improved for future implementation. Table 7 shows how students perceive ODL should be conducted. 
Table 7: Implementation of ODL Should be Improved

\begin{tabular}{|c|l|}
\hline 12 & $\begin{array}{l}\text { "I really hope that ODL is not a things that burdensome the student, but a way that } \\
\text { makes learning more fun." }\end{array}$ \\
\hline 13 & $\begin{array}{l}\text { "ODL is great for certain subject but when the subject is hands on i think it is not great } \\
\text { idea to do ODL, I hope in the future there is better strategy for student that need hands } \\
\text { on assignment instead of making a video so that they can get the experience." }\end{array}$ \\
\hline 17 & "Can make less pressure and more fun" \\
\hline 18 & "the class will become more lively" \\
\hline 19 & $\begin{array}{l}\text { "I hope ODL can be more creative in aproaching students so student can be more } \\
\text { excited enough for having classes" }\end{array}$ \\
\hline 20 & $\begin{array}{l}\text { "I hope ODL will be even more fun and happening. Besides, not a burden or pressure } \\
\text { to the students because it can cause mental health" }\end{array}$ \\
\hline 22 & "I hope that there will be more individual assignment" \\
\hline 26 & "I hope ODL will help many student in achieve their studies" \\
\hline 27 & "I hope ODL can give me a good results based on my efforts" \\
\hline 28 & $\begin{array}{l}\text { "I hope I will get As for my ELC231 because in my semester 1 and semester 2, I always } \\
\text { get B+ only" }\end{array}$ \\
\hline 29 & "I hope the output that i can get from ODL will be the same as normal class" \\
\hline 30 & "Getting pass as face to face learning" \\
\hline 31 & "i hope i still can get a great pointer eventhough learning in ODL" \\
\hline 32 & "To get a better results" \\
\hline 33 & "Get the best results" \\
\hline 34 & $\begin{array}{l}\text { "I hope the I will get a better result in ODL as the questions for tests and quizzes are } \\
\text { quite hard." }\end{array}$ \\
\hline 35 & "i hope i can survive ODL and get dean list for this current semester." \\
\hline
\end{tabular}

Table 7 shows actual quotes from respondents on why they want to enhance ODL in the future. It was discovered that the majority of pupils are bored and require more diversity in their classes. The majority of them used words like "fun," "interesting," "relax," "lively," and "enjoyable" to indicate that they required some diversity in their teaching method. Furthermore, Extract No. 19 clearly demonstrates the pressure on instructors to "be more innovative" when interacting with students. Students also expect teachers to be flexible with assignments submission and to minimise the number of assignments by giving students more hands-on activities rather to merely filming video presentations, which might cause stress. Furthermore, pupils' academic achievement is a major issue during ODL. Even though they are in ODL mode, students expect high outcomes. Their desire to achieve excellent marks demonstrates that they are concerned about the study mode. Students, as indicated in Table 7, are quite optimistic about getting excellent results during this ODL in order to "not anger their parents," "not repeat subjects," and "stay on the dean's list." Because the questions and quizzes assessed in the examination were viewed as "very difficult," the majority of respondents placed high expectations in ODL in the future to help them with their grades and prevent failing. Furthermore, several of the respondents anticipated that ODL would not influence their results because they had previously performed well in physical classes. 


\section{Discussions}

The findings of this study indicated that when adjusting to the new learning method in ODL mode, students have a variety of experiences. The most common method for attending lessons in ODL, according to the respondents in this research, was through Google Meet. Regardless of the platform they use to connect, the majority of the respondents attended all of the classes. Furthermore, computers and mobile phones were found to be the most often used devices for ODL by respondents, with the majority having their own gadgets for ODL. Only a small percentage of respondents admitted to using other family members' devices. This findings is in contrast with those found by Yeoh (2020) who claimed that Malaysia as a whole is not ready for a virtual system because most pupils in rural schools do not possess phones and struggle with e-learning during MCO. The current study highlights that all students had their own electronic devices for studying, with only a small number of students using their parents' or family members' devices.

It should also be highlighted that under ODL, assignment submission was mostly done through Microsoft Teams. Although Google Meet was the primary platform for virtual learning, Microsoft Teams and followed by Google Drive was the favourable platform to submit assignment. The participants' expectations on ODL educational decisions were another conclusion of the current study. Students had three primary expectations about ODL, the most important of which was to stop using virtual mode and return to face-to-face instruction. This is in line with earlier research, which indicated that students were unsatisfied with the implementation of virtual learning mode and hoped for improvements (Abbasi et al., 2020; Aiman, 2020). However, the findings contradicts with studies that suggest respondents feel comfortable studying in an online environment despite the lack of personal connection (Khan et al., 2021; Singh \& Thurman, 2019).

Interestingly, it is worth highlighting that although respondents are able to undergo studying ODL, they still believed ODL was unsuccessful. They were dissatisfied with the ODL instructional mode. There are also participants who found ODL was difficult to adapt with. Some even expressed that if ODL continues, they may have to drop out of school, since they have trouble comprehending courses in ODL and hoping for less stress from the assignments they receive from lecturers. This contradicts the findings of Sit, Chung, Chow, and Wong (2005), who discovered that pupils can comprehend concepts presented in topics when online learning. The current study also discovered that students are still struggling to adapt ODL and master their courses. This is in-line with previous studies that found ODL to be stressful (Chung, Weng, \& Chen, 2018) and difficult to understand subject matter (Vanslambroucka et al., 2018; Bali \& Liu, 2018; Chung, Chow \& Woo, 2018). and increased workload (Vanslambroucka et al., 2018; Ravi, 2014).

\section{Conclusions}

The major finding of the current study is that students use a variety of platforms for ODL, including Google Meet, Microsoft Team, YouTube, and Zoom. Google Meet is the most popular platform. Another hopeful element worth mentioning is that Malaysia is prepared to move toward ODL because the vast majority of students use their own electronic devices for study purposes, with only a small percentage using their parents' or family members' devices. Students, however, are dissatisfied with the adoption of ODL and believe that it should be phased out in the future since it is ineffective, difficult to adapt, and difficult to grasp subject matter. Nevertheless, students are hopeful that ODL lessons will be more interactive, creative and less stressful. Results in the present study have several implications for educators, 
curriculum designers and universities to improve ODL experiences for Diploma course students. Educators need to design lessons creatively so as to not overburden students with boredom, assignments and group activities while in ODL. Students as the new generation, despite surrounded with technology still require creatively designed lessons to retain their attention span on subject matter and reduce mobile data usage (Sim, Sim, \& Quah, 2021) to less income families.

Lecturers are suggested to include games to make lessons more interesting. The delivery of lessons can also be livelier and attracts full attendance to ODL classes. Educators can also provide for flexibility in assignment submission by offering a variety of activities, mode of conducting lesson tasks, and mutual agreement on assignment deadlines. Allowing students to choose their own assignment rules will encourage millennials to be more creative. This is consistent with Constructivism's ODL theory, which encourages autonomous learners who create their own knowledge through exploration through experience in ODL mode. As on the part of the higher learning institutions, proper management of internet facilities, technical support and training of staff and students need to be conducted for efficacy of ODL implementation. Even though the students have their own gadgets, they expectations for ODL in the future. Each of the expectations should be considered seriously as they can have implications during lessons.

In general, the findings from the present study contribute to the existing literature on ODL as in the future if more ODL will be the trend in tertiary education especially for Diploma course students, proper measures as suggested in this study should be considered in advance. The findings provide a basis to meet the aspirations of the government in the Education Blueprint, 2013-2025 (Ministry of Education Malaysia, 2013) on the need to transform education for more tech-based lessons for the millennials. Thus, there is a need to properly planned ODL implementation with full support from all involved in ODL mode.

\section{Acknowledgement}

The authors would like to thank the Universiti Teknologi MARA Johor for the funding received under the BESTARI Grant Phase 2/2020 to support this study.

\section{References}

Alea, L. A., Fabrea, M. F., Roldan, R. D. A., \& Farooqi, A. Z. (2020). Teachers' Covid-19 awareness, distance learning education experiences and perceptions towards institutional readiness and challenges. International Journal of Learning, Teaching and Educational Research, 19(6), 127-144.

Author, 52 peratus pelajar Sabah tiada akses internet. (2020). Berita Harian Online.Retrieved: https://www.bharian.com.my/berita/nasional/2020/05/686499/52peratus-pelajar-sabah-tiada-akses-internet (accessed 8 March, 2021)

Abbasi, S., Ayoob, T., Malik, A, \& Memon, SI. (2020). Perceptions of students regarding Elearning during Covid-19 at a private medical college. Pak J Med Sci. 36(COVID19S4):COVID19-S57-S61. https://doi.org/10.12669/pjms.36.COVID19-S4.2766

Aiman, A. (2020). Improve online learning for pupils still stuck at home, say activists.Retrieved: https://www.freemalaysiatoday.com/category/nation/2020/06/11 /improve-online-learning-for-pupils-still-stuck-at-home-say-activists/ (accessed 16 June, 2020).

Ally, M. (2004). Foundations of educational theory for online learning. Theory and practice of online learning, 2, 15-44. 
Anderson, M., \& Perrin, A. (2018). Nearly one-in-five teens can't always finish their homework because of the digital divide. Pew Research Center. Retrieved from https://www.pewresearch. org/fact- tank/2018/10/26/nearly-one-in-five-teenscantalways-finish-their-homework-because-of-the- digitaldivide/.

Bączek, M., Zagańczyk-Bączek, M., Szpringer, M., Jaroszyński, A., \& Wożakowska-Kapłon, B. (2021). Students' perception of online learning during the COVID-19 pandemic: a survey study of Polish medical students. Medicine, 100(7).

Bali, S., \& Liu, M. C. (2018). Students' perceptions toward online learning and face-to-face learning courses. Journal of Physics: Conference Series 1108, p. 1-8. DOI:10.1088/1742$6596 / 1108 / 1 / 012094$

Benson, A. D. (2002). Using online learning to meet workforce demand: A case study of stakeholder influence. Quarterly review of distance education, 3(4), 443-52.

Carliner, S., \& Boswood, T. (2004). Genre: A useful construct for reseaching online communication for the workplace. Information Design Journal, 12(2), 124-136.

Chuang, H. H., Weng, C. Y., \& Chen, C. H. (2018). Which students benefit most from a flipped classroom approach to language learning? British Journal of Educational Technology, 49(1), 56-68.

Chung, E., Noor, N. M., \& Mathew, V. N. (2020). Are you ready? An assessment of online learning readiness among university students. International Journal of Academic Research in Progressive Education and Development, 9(1), 301-317.

Clark, H. (2002). Building Education: The Role of the Physical Environment in Enhancing Teaching and Research. Issues in Practice. Institute of Education, 20 Bedford Way, London, WC1H OAL, England.

Conrad, D. L. (2002). Engagement, excitement, anxiety, and fear: Learners' experiences of starting an online course. The American journal of distance education, 16(4), 205-226.

Demuyakor, J. (2020). Coronavirus (COVID-19) and Online Learning in Higher Institutions of Education: A Survey of the Perceptions of Ghanaian International Students in China. Online Journal of Communication and Media Technologies, 10(3), e202018. https://doi.org/10.29333/ojcmt/8286

Ellis, R. (2005). Principles of instructed language learning. System, 33(2), 209-224.

Funa, A. A., \& Talaue, F. T. (2021). Constructivist Learning Amid the COVID-19 Pandemic: Investigating Students' Perceptions of Biology Self-Learning Modules. Online Submission, 20(3), 250-264.

Gonzalez, T., de la Rubia, M. A., Hincz, K. P., Comas-Lopez, M., Subirats, L., Fort, S., \& Sacha, G. M. (2020). Influence of COVID-19 confinement in students' performance in higher education. arXiv preprint arXiv:2004.09545.

Harasim, L. (2012). Learning theory and online technologies. New York: Routledge/Taylor \& Francis.

Hiltz, S. R., \& Turoff, M. (2005). Education goes digital: The evolution of online learning and the revolution in higher education. Communications of the ACM, 48(10), 59-64.

Kapasia, N., Paul, P., Roy, A., Saha, J., Zaveri, A., Mallick, R., ... \& Chouhan, P. (2020). Impact of lockdown on learning status of undergraduate and postgraduate students during COVID-19 pandemic in West Bengal, India. Children and Youth Services Review, 116, 105194.

Krejcie, R. V., \& Morgan, D. W. (1970). Determining sample size for research activities. Educational and psychological measurement, 30(3), 607-610. 
Lau, C. Y., \& Shaikh, J. M. (2012). The impacts of personal qualities on online learning readiness at Curtin Sarawak Malaysia (CSM). Educational Research and Reviews, 7(20), 430-444.

Lee, S. (2020). Sabah student stays overnight in tree to get better Internet connectionforonlineuniversityexams.Retrieved: https://www.thestar.com.my/news/n ation/2020/06/16/sabah-uni-student-stays-overnight-in-tree-to-get-better-internetconnection-for-online-exams (accessed 8 March, 2021).

Lowenthal, P. R., Wilson, B., \& Parrish, P. (2009). Context matters: A description and typology of the online learning landscape. In AECT International Convention, Louisville, $K Y$.

Ministry of Health Malaysia. (2020). Covid-19 Malaysia: Distribution of Covid-19 cases according to date of confirmation. http://covid-19.moh.gov.my/

Mathew, V., \& Chung, E. (2021). University Students' Perspectives on Open and Distance Learning (ODL) Implementation Amidst COVID-19. Asian Journal of University Education, 16(4), 152-160.

Paul, J., \& Jefferson, F. (2019). A comparative analysis of student performance in an online vs. face-to-face environmental

Moore, M. (2010). Independent study. In Redefining the Discipline of Adult Education, eds. Boyd, R., J.W. Apps and Associates, 16-31. San Francisco: Jossey-Bass.

Murphy, M. P. A. (2020). COVID-19 and emergency eLearning: Consequences of the securitization of higher education for post-pandemic pedagogy. Contemporary Security Policy, 1-14. https://doi.org/10.1080/13523260.2020.1761749

Nichols, M. (2003). A theory for eLearning. Journal of Educational Technology \& Society, 6(2), 1-10.

Oblinger, D., Oblinger, J. L., \& Lippincott, J. K. (2005). Educating the net generation. Boulder, Colo.: EDUCAUSE, c2005. 1 v.(various pagings): illustrations.

Paul, J., \& Jefferson, F. (2019). A comparative analysis of student performance in an online vs. face-to-face environmental science course from 2009 to 2016. Frontiers in Computer Science, 1, 7.

Pelmin, M. (2020).Readings on Coronavirus Disease (COVID-19) and the Higher Education Institution (HEIs) Emergency Preparedness in the Philippines. Available at SSRN 3573896. https://ssrn.com/abstract $=3573896$

Picciano, A. G. (2017). Theories and frameworks for online education: Seeking an integrated model. Online Learning, 21(3), 166-190. doi: 10.24059/olj.v21i3.1225

Ravi Seethamraju. (2014). Effectiveness of Using Online Discussion Forum for Case Study Analysis. Education Research International, 1-11.

Selvanathan, M., Hussin, N. A. M., \& Azazi, N. A. N. (2020). Students learning experiences during COVID-19: Work from home period in Malaysian Higher Learning Institutions. Teaching Public Administration, 0144739420977900.

Sim, S. P. L., Sim, H. P. K., \& Quah, C. S. (2021). Online Learning: A Post Covid-19 Alternative Pedagogy For University Students. Asian Journal of University Education, 16(4), 137-151

Singh, V., \& Thurman, A. (2019). How many ways can we define online learning? A systematic literature review of definitions of online learning (1988-2018). American Journal of Distance Education, 33(4), 289-306.

Sit, J. W. H., Chung, J. W. Y., Chow, M. C. M., \& Wong, T. K. S. (2005). Experiences of online learning: students' perspective. Nurse Education Today, 25(2), 140-147.

Tavangarian, D., Leypold, M. E., Nölting, K., Röser, M., \& Voigt, D. (2004). Is e-Learning the Solution for Individual Learning?. Electronic Journal of E-learning, 2(2), 273-280. 
Vanslambroucka, S., Zhu, C., Lombaerts, K., Philipsen, B., \& Tondeur, J. (2018). Students' motivation and subjective task value of participating in online and blended learning environments. The Internet and Higher Education, 36, 33-40.

Wang, H. (2014). Learner autonomy based on constructivism learning theory. International Journal of Cognitive and Language Sciences, 8(5), 1552-1554.

World Health Organization. (2020). COVID-19 in Malaysia. Retrieved from https://www.who.int/southeastasia on 1 November 2020.

Yeoh, A. (2020) MCO: as lessons move online, local teachers and students struggle with uneven Internet access. Retrieved from: https://www.thestar.com.my/tech/technews/2020/04/27/mco-as-lessons-move-online-local-teachers-and-students-strugglewith-uneven-internet-access (accessed 20 January, 2020). 